\title{
ARCHEOLOGIA KRAJOWA NA LAMACH „TYGODNIKA ILUSTROWANEGO” DO 1886 ROKU
}

SŁowa KluCzowe: historia archeologii; ,Tygodnik Ilustrowany”; zabytki

KEYwORDs: history of archeology; "Tygodnik Ilustrowany"; archaeological monuments

$\mathrm{Na}$ całokształt ubiegłych pokoleń składa się cała mozajka szczegółów, w której każdy kamyk ma swój odrębny wyraz, swoją fizynomię nieraz bardzo wymowną. Poszanowanie dla przeszłości u narodów kulturalnych wyraża się między innemi w zabiegliwości, jaką dane społeczeństwo roztacza nad pomnikami i relikwiami minionych epok. [...] Muzeów publicznych prawie nie było; zadania wychowawcze tego rodzaju instytucyi spełniać mogły jedynie wydawnictwa ilustrowane, pomieszczając $\mathrm{w}$ dokładnem odtworzeniu przeróżne zabytki dawnych wieków bytowania narodu.

„Tygodnik”, zaraz w początkach swych podjął ten obowiązek zaszczytny; istne w nim muzeum narodowe, barwne, jak przeszłość, bogate a miłowane (Archeologia... 1909: 1045-1046).

„Tygodnik Ilustrowany” był społeczno-kulturalnym czasopismem, które ukazywało się w latach 1859-1939. Powstał z inicjatywy Franciszka Maksymiliana Sobieszczańskiego (1814-1878), z zawodu cenzora, a z zamiłowania historyka i badacza starożytności. Wydawcą magazynu został znany warszawski drukarz - Józef Unger (1817-1874), który pod koniec 1858 r. zjawił się w mieszkaniu Ludwika Jenikego (1818-1903), literata i dziennikarza, proponując mu objęcie posady redaktora w mającym powstać piśmie. Powierzoną funkcję L. Jenike pełnił do 1886 r. Niewątpliwie jego postać zaważyła na charakterze periodyku. Choć, jak wiadomo, w procesie kształtowania oblicza ,Tygodnika” uczestniczyło wiele osób (Jenike 1910: 41). O celach jakie mu postawiono możemy przeczytać w czterostronicowym „Prospekcie” z dnia 20 sierpnia 1859 r.:

Wyjąwszy wypadki spółczesne, życiorysy, postęp nauk przyrodzonych, przemysłu i wynalazków, oraz sztuki piękne, które to działy z natury swojej obejmować 
muszą i ważniejsze rzeczy zagraniczne, barwa Tygodnika będzie czysto krajowa. Zbierając skrzętnie i wydzierając zapomnieniu wszystko co tylko ma związek $\mathrm{z}$ przeszłością, wszystko $\mathrm{w}$ czem tętni życie narodowe, pismo to stanie się kiedyś zbiorem całkowitym godniejszych uwagi wspomnień historycznych, opisów i rysunków, bogatym składem zostawionej nam po przodkach puścizny, w której rozpatrując się, poznamy samych siebie (Unger 1959).

Po zapoznaniu się z tym krótkim fragmentem wiadomo, że głównym zadaniem założycieli było stworzenie pisma, które będzie zajmowało się sprawami krajowym. W „Tygodniku”, w związku z tym, podejmowano również zagadnienia wiążące się z historią oraz wówczas jeszcze szeroko rozumianymi „starożytnościami”. Ostatni termin obejmował znacznie więcej niźli tylko zabytki archeologiczne. Pod pojęciem tym kryły się wszystkie świadectwa narodowej przeszłości od czasów najdawniejszych po współczesne XIX-wiecznym twórcom pisma (Szczerba 2012: 17). W niniejszym artykule uwzględniam jedynie zabytki archeologiczne. Tekst został podzielony na części poświęcone: wykopaliskom, odkryciom przypadkowym, kolekcjom prywatnym, wystawom i muzeom starożytności oraz innym wiadomościom, które wiązały się z archeologią.

\section{WYKOPALISKA I ODKRYCIA PRZYPADKOWE}

Wykopaliska z reguły były wynikiem wpierw dokonanych przypadkowo odkryć. Nie wszystkie z nich w XIX wieku kończyły się systematycznymi pracami. Zabytki z czasów „pogańskich” odkrywano podczas budowy kościołów, kolei itp. Zwracano uwagę, nie tylko na cmentarzyska i ich pozostałości w postaci urn, ale także kości zwierząt uznawanych za kopalne, współczesne człowiekowi pierwotnemu (Kronika ... 1875, XVI, 394: 34). Często udawało się określić ich przynależność do konkretnego gatunku. Tak było w przypadku mamuta znalezionych w Podhorcach na Bukowinie, o czym informowano na kartach warszawskiego periodyku (Korespondencja... 1870: 177-178).

Znaleziska wymarłych zwierząt $w$ latach 70. i 80. XIX stulecia wzbudzały szczególne zainteresowanie uczonych, ze względu na badania jakie prowadzono na zachodzie Europy. Sławne były wyniki naukowych dociekań Jacquesa Bouchera de Perthes'a (1788-1868), celnika o arystokratycznym pochodzeniu, geologa i badacza najdawniejszych dziejów. W czasie prac wykopaliskowych posługiwał się on metodą stratygraficzną. Dyscyplinę, którą zajmował się nazwał archeogeologią, uważając ją za swój wynalazek (Abramowicz 1997: 75-80).

Jacque Boucher de Perthes szukając śladów człowieka „przedpotopowego”, zajął się również potopem. Ciekawość skłoniła go także do rozważań nad lodowcami i sposobem transportowania przez nie m.in. skał i kości. Przyjął zło- 
żenie, że istniała epoka lodowa i z nią wiązał nadzieje na znalezienie człowieka, nie tylko szkieletu, ale całości, na wzór znajdowanych na Syberii mamutów (Abramowicz 1997: 93-97).

Poszukiwania człowieka przedpotopowego w oparciu o stratygrafię przyrodniczą podjął na zlecenie Komisji Archeologiczno-Antropologicznej Akademii Umiejętności, Gotfryd Ossowski (1835-1897). O jego odkryciach donoszono na łamach „Tygodnika Ilustrowanego”. W okolicach Krakowa, w warstwach wapienia jurajskiego badacz spodziewał się odnaleźć ludzkie szczątki. Jednak przeprowadzone tam poszukiwania nie przyniosły oczekiwanych rezultatów. $\mathrm{Z}$ tego powodu, gdy dotarły do niego informacje o odkryciach w Grocie Maszyckiej (faktycznie jaskini) położonej w okolicach Ojcowa, G. Ossowski postanowił się jej bliżej przyjrzeć. Rezultatem jego badań było odnalezienie ludzkiej czaszki, dużej liczby kości zwierzęcych i prymitywnych narzędzi (Plenkiewicz 1884: 45-46).

Interesujące okazały się również odkrycia w Jaskiniach Minikowskich dokonane przez tegoż badacza. Odnaleziono wówczas przedmioty kościane i kamienne z epoki przedhistorycznej. Rezultaty badań G. Ossowskiego wzbudziły wiele emocji i nie zostały przyjęte bezkrytycznie. Zarzucono mu fałszerstwo. $\mathrm{Z}$ tego powodu też z inicjatywy Akademii Umiejętności powołano specjalną komisję do zweryfikowania autentyczności odkrytych artefaktów. Ostatecznie uznano je za prawdziwe wyroby rąk ludzkich z epoki przedchrześcijańskiej (Silva... 1885: 159).

Znaleziska G. Ossowskiego były faktycznie przedmiotami pochodzącymi ze starszej epoki kamienia. Jaskinia Maszycka jest obecnie jednym z najbardziej znanych stanowisk paleolitycznych w Polsce, choć z powodu nie do końca profesjonalnych prac dziewiętnastowiecznego badacza ogromnym problemem jest wyróżnienie w niej warstw stratygraficznych (Blombergowa 2003: 140-141).

Wyniki dociekań G. Ossowskiego, właściciela Ojcowa, były popularyzowane za pośrednictwem prasy, w tym i „Tygodnika Ilustrowanego”. Roman Plenkiewicz (1833-1910), autor artykułu zamieszczonego w warszawskim periodyku, był pedagogiem, historykiem, członkiem Towarzystwa Naukowego Warszawskiego, podróżnikiem, a przede wszystkim miłośnikiem rejonu ojcowskiego. Wiele o nim pisał i śledził wszelkie prace, które tam podejmowano (Blombergowa 2003: 141-142).

Ojców po utracie niepodległości w 1795 r. był jedną z najbardziej atrakcyjnych turystycznie miejscowości. Przyjeżdżali tam malarze, poeci, uczeni itd. W 1859 r. jego właścicielem stał się Aleksander Przezdziecki (1814-1871), który oprócz prowadzonych tam badań zadbał, poprzez budowę obiektów uzdrowi- 
skowych, aby stał się on jeszcze ciekawszym atrakcyjnym miejscem wypoczynkowym. Miał w planach odbudowę wieży zamkowej. Zamierzenia te zostały zniweczone z powodu wybuchu powstania styczniowego. Nie dziwi więc fakt, że od Jana Zawiszy (1822-1887), kolejnego właściciela i badacza ziemi ojcowskiej, R. Plenkiewicz oczekiwał kontynuacji prac poprzednika (Plenkiewicz 1883: 350-351).

Niemniej interesujące dla społeczeństwa, a zwłaszcza miłośników starożytności, były znaleziska z Lednicy. Odkryto tam części broni oraz przedmioty codziennego użytku. Z tego względu Albin hr. Węsierski (1812-1875) z Zakrzewa, patriota i miłośnik starożytności, odkupił od rządu pruskiego wyspę (Fogel 1991: 9-11). W wyniku prowadzonych przez niego i A. Przezdzieckiego badań odkryto mury. Zdania dotyczące ich funkcji i chronologii były podzielone. Kazimierz Szulc uważał, że odkryto relikty pogańskiej świątyni słowiańskiej. Aleksander Przezdziecki traktował je jako pozostałość kościoła, a Joachim Lelewel widział castrum Bolesława Chrobrego (Sobieszczański 1870: 16; Abramowicz 1991: 39-40).

Artykuł opisujący podgnieźnieńskie odkrycia Franciszek Maksymilian Sobieszczański zredagował na podstawie cyklu publikacji zamieszczonych w „Bibliotece Warszawskiej” przez badacza tego stanowiska-A. Przezdzieckiego (1869).

Niemniej emocji wzbudziło odkrycie w posiadłości Karola hr. Libelta (18071875) w Jeziorze Czeszewskim regularnie rozmieszczonych słupów. Były pozostałością mieszkań na palach, nazwanych palafitami. Od połowy XIX stulecia zaczęły mnożyć się znaleziska pozostałości takich konstrukcji w jeziorach szwajcarskich. Szybko stały się one sławne w całej Europie. Wśród odsłoniętych szczątków pali znajdowano kamienne siekiery, ceramikę, narzędzia rogowe itp. Dyskutowano przy okazji tych odkryć nad chronologią zabytków. Jedni datowali je na parę tysięcy lat wstecz, inni umiejscawiali w okresie rzymskim (Abramowicz 1991: 50; Łepkowski 1871: 200).

Dzięki szczegółowym badaniom prowadzonym przez uczonych na zachodzie Europy, udało się ustalić jak wyglądały siedziby oraz jak żyli i czym zajmowali się mieszkańcy osad na palach. Józef Łepkowski (1826-1894), autor artykułu i zięć K. Libelta, posiadał informacje na temat znalezisk i ustaleń europejskich badaczy dotyczących palafitów. Czerpał je z publikacji niemieckich uczonych oraz z własnych obserwacji, gdyż uczestniczył w wykopaliskach prowadzonych na takim stanowisku (Łepkowski 1866: 28-30). 
Odkrycia dokonane w Jeziorze Czeszewskim, położonym niedaleko Nakła, były pierwszym tego rodzaju znaleziskiem na ziemiach polskich. W wielu pismach zamieszczano o nich informacje. Wzbudziły one również zainteresowanie niemieckich uczonych, którzy przyjeżdżali nad Jezioro Czeszewskie (Wiadomości... 1869b: 43).

Tuż po znalezieniu osiedli na palach na łamach warszawskiego periodyku pojawiły się oskarżenia w stosunku do odkrywcy, że zlekceważył tak ważne dla polskiej archeologii stanowisko (Czernicki 1865: 222). J. Łepkowski również w „Tygodniku Ilustrowanym”, odparł niesłuszne zarzuty. Okazało się, że dokładnie je przebadał. Konsultował się także z krakowskimi antropologami i geologami. W stosownym czasie obiecał poinformować o rezultatach swoich prac, czego jednakże nie uczynił. Wszystkie artefakty z tych wykopalisk zostały przesłane do Gabinetu Archeologicznego Uniwersytetu Jagiellońskiego, znajdującego pod opieką samego odkrywcy (Łepkowski 1871: 200-201).

W „Tygodniku” zamieszczono również opis odkrycia wielkiego cmentarzyska z Nadziejewa pod Środą. Było to zasługą pana Domaradzkiego ${ }^{1}$ - mieszkańca tejże miejscowości. Podczas kopania rowów, na zboczu nazywanym przez miejscową ludność „Modłą”, odkrył on obszerne cmentarzysko płaskie. Wydobyto z niego ponad trzysta przedmiotów glinianych, głównie popielnic o różnych kształtach. Pozostałe to tzw. przystawki, choć autor uważał, że były to pamiątki całej rodziny. Stąd miała pochodzić ich różnorodność (Niewiadomski 1870: 159). Dokładny opis odkrycia został zamieszczony w „Roczniku Towarzystwa Przyjaciół Nauk" (Domaradzki 1871: 202-218).

W większości grobów wokół popielnic i przystawek ułożone były kamienie, całość pokrywała ziemia. Zdarzały się również popielnice bez obstawy kamiennej lub same luźno rozsypane popioły. Pochówków szkieletowych nie było. W grobach odkryto jedną siekierkę kamienna, kilka przedmiotów brązowych i żelaznych (Niewiadomski 1870).

Znalezione przedmioty miały $\mathrm{w}$ opinii autora potwierdzać przekonanie, m. in. Józefa Ignacego Kraszewskiego (1812-1887), że na ziemiach polskich (z wyjątkiem terenów nadbałtyckich) współistniały wszystkie trzy epoki: kamienia, brązu i żelaza (Niewiadomski 1870).

Artykuł dotyczący wykopalisk nadziejewskich jest sygnowany inicjałami W. N. Możemy się domyślać, że jego autorem był Wincenty Niewiadomski (1826-1892), literat, samouk przyrodnik, który na łamach „Tygodnika Ilustrowanego" popularyzował głównie nauki przyrodnicze (Muszalski 1978: 78).

\footnotetext{
${ }^{1}$ Przeprowadzona kwerenda nie przyniosła rezultatów w postaci bliższych informacji o Domaradzkim.
} 


\section{KOLEKCJE PRYWATNE}

Na łamach „Tygodnika Ilustrowanego” zamieszczano także opisy zabytków, które przypadkowo znajdowano lub uzyskiwano w wyniku systematycznych badań. Początkowo najczęściej trafiały one do prywatnych zbiorów ich odkrywców lub osób nimi zainteresowanych.

Obszerną kolekcję narzędzi kamiennych zgromadził Ludwik Pawłowski (1816-1853), mieszkający w Moszczanicy Wielkiej pod Dubnem, w ówczesnej guberni wołyńskiej. Ten mało znany badacz starożytności pierwszy raz zetknął się z przedhistorycznymi zabytkami w czasie nauki w Liceum Krzemienieckim. Wtedy też zainteresował się archeologią i numizmatyką. Wiele podróżował, aby pozyskać nowe eksponaty do swej kolekcji monet: polskich, ruskich oraz starożytnych greckich i rzymskich. Zebrał ich około 500 sztuk (Gloger 1880: 11).

Równie interesujące były przedmioty kamienne, które znalazły się w posiadaniu L. Pawłowskiego. Pochodziły one z badań prowadzonych w Moszczanicy i jej okolicach. W zbiorze znalazły się m.in.: osełki, kliny, noże, sierpy, strzały, beredysze ${ }^{2}$ oraz kamienie procowe (Gloger 1880).

Choć sam kolekcjoner nie upowszechniał wiedzy na temat swoich zabytków na łamach prasy to posiadamy ich opisy dzięki J. I. Kraszewskiemu, który wiadomości o nich zawarł w pracy Sztuka u Stowian. Część z nich J. I. Kraszewski otrzymał w prezencie. Pewną ich liczę synowiec Pawłowskiego - Aleksander, po jego śmierci podarował Gotfrydowi Ossowskiemu. Część zabytków otrzymał od Aleksandra Pawłowskiego również autor artykułu Zygmunt Gloger (1845-1910), który także pasjonował się archeologią i kolekcjonował starożytności krajowe. Informacje na temat L. Pawłowskiego posiadał od jego rodziny i przyjaciela J. I. Kraszewskiego. Dzięki nim przetrwała pamięć o niestrudzonym badaczu najdawniejszych dziejów Wołynia (Gloger 1880).

Narzędzia kamienne znalazły się także w zbiorze Józefa Przyborowskiego (1823-1896), archeologa, bibliografa, językoznawcy i numizmatyka. Był on związany z Szkołą Główną w Warszawie, również po jej przekształceniu w Uniwersytet, gdzie prowadził wykłady z historii języka polskiego (później lektorat języka niemieckiego) i przez pewien czas zajmował się biblioteką (Kryński 1882: 162).

${ }^{2}$ Beredysze: „tak nazwane przez ś. p. Pawłowskiego narzędzia różnią się od dłut i klinów, znacznie większą grubością i brakiem kantów po bokach, a wypukłością pośrodku, od którego spuszczone są zlekka i oszlifowane najostrzej, tak, że niektóremi z nich dotąd krajać można. Kończą się zawsze linją zaokraggloną, a tylec mają tylko zgruba obrobiony. Długość ich różna, od dwóch do siedmiu cali, krótsze zdają się być na wpół rozbite. Odznacza je nadzwyczaj staranne obrobienie ostrza" (Kraszewski 1860: 37). 
Archeologią J. Przyborowski zainteresował się dopiero około 1870 r. i od tego momentu stała się ona jego życiową pasją. Wraz ze swymi synami i kuzynem badał, wybrzeża Wisły: pod Płockiem, w okolicach Warszawy, nad rzekami Wkrą, Świdrem, Tyśmienicą i Wieprzem. Rezultatami jego poszukiwań były odkrycia narzędzi kamiennych, popielnic, żalników. Informacje o nich zamieszczał w redagowanym przez siebie od 1872 r. piśmie „Wiadomości Archeologiczne”, które finansował Jan Zawisza (Kryński 1882).

Najsławniejsze spośród wszystkich eksponatów J. Przyborowskiego były strzałki i narzędzia krzemienne pochodzące $\mathrm{z}$ tzw. stacji krzemiennych. Jego zasługą było wyodrębnienie narzędzi mikrolitycznych. Eksponowano je w czasie Kongresu Archeologicznego w Peszcie w 1876 r. (Kryński 1882; Wrońska-Twardecka 1997: 315).

Adam Antonii Kryński (1844-1832), autor artykułu poświęconego J. Przyborowskiemu, był jego uczniem i podobnie jak on zajmował się językoznawstwem. W późniejszym czasie wykładał jako profesor w Uniwersytetach Warszawskim i Lwowskim. Ucznia z Mistrzem łączyły nie tylko wspólne badania nad językiem i twórczością Jana Kochanowskiego, ale także praca nad tworzeniem Stownika języka polskiego (Skręt 1986: 78; Fita 1980: 64). Na tej podstawie można wnioskować, że artykuł o J. Przyborowskim został napisany na podstawie wspomnień i informacji wcześniej uzyskanych od zmarłego.

\section{WYSTAWY I MUZEA STAROŻYTNOŚCI}

Jednym ze sposobów upowszechniania wiedzy o historii i kulturze polskiej po klęsce powstań stały się wystawy starożytności. Po ich zakończeniu często tworzono katalogi. Na łamach „Tygodnika” pojawiały się informacje na ich temat wraz z adnotacją o cenie i możliwości nabycia (Doniesienia 1860: 123). Należy zauważyć, że ukazanie się albumów z pierwszych dwóch wystaw starożytności na ziemiach polskich (w Warszawie - 1856 r. i Krakowie - 1858 r. i 1859 r.) było zasługą Karola Beyera (1818-1877), jednego z twórców „Tygodnika Ilustrowanego", będącego właścicielem zakładu fotograficznego w Warszawie, który, co warto podkreślić, wydał je własnym nakładem (Sobieszczański 1877: 314).

Pierwsze wystawy zaczęto organizować już na początku 2. połowy XIX w. Wszystkie były tworzone z ogromnym rozmachem. Na łamach warszawskiego periodyku publikowano sprawozdania z części z nich, choć niekiedy redaktorzy ograniczali się jedynie do krótkiej noty zamieszczonej w „Kronice Tygodniowej” (tak było głównie w pierwszych latach istnienia pisma).

Początkowo zabytki gromadzono w prywatnych kolekcjach. $Z$ tego powodu, gdy planowano zorganizować wystawę, w prasie pojawiał się apel o nadsyłanie 
eksponatów. W „Tygodniku Ilustrowanym” opublikowano prośbę organizatorów krakowskiej Wystawy starożytności i zabytków sztuki, która miała odbywać się w dniach od 1 grudnia 1872 r. do 15 stycznia 1873 r. Prośba skierowana została do kolekcjonerów, instytucji publicznych, a także kościołów i klasztorów. Warszawski periodyk zawsze przychylnie odnosił się do tego typu inicjatyw, popierając je i promując na swoich łamach (Kronika... 1872b: 246).

Na kartach „Tygodnika Ilustrowanego” możemy znaleźć, krótką wzmiankę o Wystawie archeologiczno-artystycznej zorganizowanej w Radomiu w 1884 r., na której zaprezentowano zabytki i starożytności z tego miasta i jego najbliższych okolic (Kronika... 1884: 23).

Wystawy były traktowane jako substytut muzeum starożytności. Postulaty założenia takiej instytucji wysuwano już od czasów Stanisława Augusta Poniatowskiego. W setnym numerze „Tygodnika” z 1869 r. donoszono o powstaniu Muzeum Starożytności w Warszawie. Jak podaje anonimowy autor notatki, jego twórcą był Hipolit Skimborowicz (1815-1880), dziennikarz, bibliograf, kolekcjoner i podbibliotekarz w Bibliotece Głównej mieszczącej się w Pałacu Kazimierzowskim na Krakowskim Przedmieściu w Warszawie. Zabytki, które tam zebrano i zinwentaryzowano, pochodziły z różnych pomieszczeń uniwersyteckich (po których były rozrzucone) i darów (np. współpracującej z „Tygodnikiem” Deotymy czyli Jadwigi Łuszczewskiej (1834-1908) i Franciszka Maksymiliana Sobieszczańskiego). Oprócz przedmiotów uzyskanych w wyniku wykopalisk w zbiorze znalazły się również obrazy, zbroje i stroje. $Z$ tych przedmiotów powstało muzeum, które zajęło dwie połączone arkadami sale na parterze pałacu. Muzeum traktowane jako agenda Biblioteki było nierozerwalnie z nią związane. W $1871 \mathrm{r}$. tuż przed jego likwidacją odwiedził je dr Zygmunt Celichowski (1845-1923), kierownik Biblioteki i Muzeum Działyńskich w Kórniku, oceniając zbiór jako skromny i nie wyróżniający się ani bogactwem ani doborem (Muzeum... 1869: 264-265; Kozerska 1967: 94-95).

Jednak już w 1871 r. Wacław Szymanowski (1821-1886) ponownie apelował w Kronice Tygodniowej o stworzenie muzeum, w którym zostałyby zgromadzone eksponaty archeologiczne, gdyż jak twierdził, dochodzą do niego informacje o wielu odkryciach $\mathrm{i}$ wykopaliskach. W jego opinii $\mathrm{z}$ takiej obfitości zabytków można było stworzyć nawet niejedno muzeum. Podkreślał ich wartość dla poznania czasów przedhistorycznych i historycznych (Szymanowski 1871: 26).

W 1880 r. redakcja „Tygodnika Ilustrowanego" poparła pomysł powołania do życia takiej jednostki wysunięty przez „Przegląd Tygodniowy”. Zwłaszcza, że w tym czasie funkcjonował przepis prawny, na mocy którego z obszarów, gdzie nie istniało muzeum prowincjonalne, wszystkie odkryte artefakty miały być prze- 
słane do muzeum znajdującego się w Sankt Petersburgu. Z prośbą tą zwrócono się w artykule do prof. Adolfa Pawińskiego (1840-1896), który w tym czasie był kuratorem zbiorów znajdujących się przy Carskim Uniwersytecie Warszawskim. Dodatkowo systematycznie poszerzał on swoją wiedzę na temat starożytności uczestnicząc międzynarodowych kongresach archeologicznych i antropologiczno-archeologicznych (Kronika ... 1880a: 74).

Zanim powstało muzeum archeologiczne zbiory starożytności, jak już wspominałam, były kolekcjonowane przez prywatnych zbieraczy, ale także przez muzea lub zakłady naukowe specjalizujące się w innych dziedzinach niż archeologia, lecz tworzące w swoim obrębie gabinety lub działy poświęcone zabytkom przedhistorycznym (Abramowicz 1991: 31).

W 1864 r. w Kronice Tygodnika Ilustrowanego donoszono o reorganizacji Muzeum Starożytności przy powołanym do życia w 1817 r. Zakładzie Narodowym im. Ossolińskich, prężnie działającej do dziś instytucji kulturalno-naukowej. Było to zasługą Ksawerego Godebskiego (1801-1869), kustosza, skryptora i konserwatora Muzeum (E. 1867: 13). On uporządkował i skatalogował zbiory starożytności i dawnych pamiątek, które znajdowały się w różnych pomieszczeniach Zakładu i umieścił w specjalnie do tego celu przeznaczonych gablotach. Eksponowano przedmioty wykopane z ziemi z wszystkich trzech epok, najstarsze rękopisy, numizmaty i medale, ryciny i inne osobliwości, jak np. Koran zabrany z obozu Kara Mustafy po zwycięskiej bitwie pod Wiedniem. Choć niektóre z nich nie prezentowały większej wartości to przechowywano je ze względów sentymentalnych i z powodu oryginalności (Zawadzki 1864: 330-331; Fischer 1927).

W 1869 r. w znajdujemy wzmiankę w Korespondencji Tygodnika Ilustrowanego o skatalogowaniu zbiorów bibliotecznych i muzealnych Towarzystwa Przyjaciół Nauk Poznańskiego. Jest to ważne, ponieważ w Wielkim Księstwie Poznańskim były to jedyne zbiory archeologiczne o charakterze publicznym. Muzeum Starożytności Polskich i Słowiańskich powstało pod koniec lat 50. XIX wieku. Eksponaty, które znalazły się w tej placówce, były głównie darami od przypadkowych odkrywców³ , a w późniejszym czasie również wynikiem systematycznych prac wykopaliskowych prowadzonych przez Komisję Archeologiczną powstałą w ramach Towarzystwa (Abramowicz 1991: 38-39).

W dziesięć lat po powstaniu Muzeum, liczyło ono: 2747 monet, 128 medali, 2360 eksponatów kamieni i kruszców oraz 763 zabytki archeologiczne. Były

${ }^{3}$ Przykładem może być zbiór naczyń z Nadziejewa opisany w podrozdziale Wykopaliska i znaleziska przypadkowe, który przekazano poznańskiemu Muzeum. 
one udostępniane wszystkim zainteresowanym (Korespondencja... 1869: 154).

Wydawać by się mogło, że liczba zgromadzonych artefaktów była duża, jednak podobnie jak w Warszawie, taki i w Poznaniu obawiano się, że publiczny zasób muzealny nie jest bezpieczny i łatwo może przepaść. $Z$ tego powodu wiele osób swoje prywatne kolekcje przechowywało w domu, nie udostępniając szerszemu gronu zainteresowanych (Abramowicz 1991: 39).

W ośrodku galicyjskim również kolekcjonowano przedmioty pochodzące z wykopalisk. Zostały one jednak zgromadzone nie w muzeum, a w Gabinecie Archeologicznym. Powstał on z inicjatywy Józefa Łepkowskiego w 1858 r., początkowo przy Towarzystwie Naukowym, a po jego reorganizacji przeszedł pod opiekę Akademii Umiejętności. Gdy J. Łepkowski uzyskał habilitację z archeologii (1862 r.), a później nominację na profesora (1866 r.), zaczął zbierać osobno artefakty dla Gabinetu Katedry Archeologii Uniwersytetu Jagiellońskiego. Oficjalnie Gabinet Katedry Archeologii powstał 5 marca 1867 r. Pierwsze zajęcia z wykorzystaniem zgromadzonych w nim eksponatów odbyły się w 1869 r. W tym samym roku została wydana przez Namiestnictwo Galicji odezwa, w której nakazywano, aby wszelkie wykopaliska przesyłać do Gabinetu Starożytności Uniwersytetu w Krakowie (Wiadomości 1869a: 228).

Stały lokal Gabinet otrzymał dopiero w 1871 r., a były to pomieszczenia na parterze Collegium Maius. Eksponaty pochodziły głównie od ofiarodawców, z tego też powodu ich nazwiska postanowiono upamiętnić w nazwach sal. $\mathrm{W}$ pierwszej z nich znalazły się przedmioty z wykopalisk. Były to dary rodziny Przezdzieckich. Drugą salę starożytności klasycznych wypełniły zabytki ofiarowane przez Czartoryskich, a trzecią dedykowano baronowi Edwardowi Rastawieckiemu (1804-1874) - historykowi sztuki i kolekcjonerowi, badaczowi polskiej kultury antycznej (Ryszkiewicz 1987: 600). W niej umieszczono przedmioty nowożytne (Żmigrodzki 1877: 151; Ostrowski 2002).

Pierwsza sala Gabinetu poświęcona była wykopaliskom z czasów przedchrześcijańskich. Znalazł się w niej obszerny zbiór popielnic i narzędzi krzemiennych. Znaleziska z epoki brązu były reprezentowane przez: bransolety, naramienniki, naszyjniki, zapinki, bardzo podobne, jak zauważył autor, do artefaktów odkrywanych w Grecji i we Włoszech. Ciekawe były również wykonane z brązu grzebienie z łańcuszkiem do noszenia na szyi. Zagadkę stanowiły szklane kule napełnione płynem nazywane potocznie łzawicami (były to naczynia, w których miały znajdować się łzy opłakujących zmarłego, a faktycznie były to przystawki grobowe). W Gabinecie przechowywano również przedmioty ze złota i srebra. Epokę żelazną reprezentowały długie szpile, bransolety, pier- 
ścienie i nóż. Ciekawymi eksponatami były kamienne posążki dwóch bóstw. W tym pomieszczeniu znalazł się również rysunek przedstawiający mieszkania na palach (Żmigrodzki 1877: 153, 164).

W drugiej sali umieszczono zabytki greckie, rzymskie, etruskie oraz egipskie. Główną atrakcją tego pomieszczenia był sarkofag z mumią. W zbiorze znalazły się również urny, amfory, noże oraz małe naczynia i lampki z gliny (Żmigrodzki 1877: 164).

Sala trzecia była skromniej wyposażona od pozostałych i mała charakter bardziej gabinetu pamiątek niż naukowej ekspozycji. Znalazły się w niej marmurowe popiersie Wita Stwosza wraz z częścią dokumentacji sporządzonej przez mistrza. Godnymi uwagi były również hełm z XI wieku i portrety trumienne. Dodatkowo srebrne puchary, oznaki godności (laski marszałkowskie, buzdygany), majoliki, porcelana i kafle (Żmigrodzki 1877: 166-167, 186).

Doktor Michał Żmigrodzki (1848-1919), autor artykułu, był literatem, bibliotekarzem, historykiem sztuki, etnografem i miłośnikiem starożytności. Ukończył studia w Uniwersytecie Jagiellońskim, a wiedzę tam zdobytą uzupełniał w zagranicznych uczelniach. Był on również związany z krakowską Akademią Umiejętności. Uczestniczył w pracach Komisji Archeologicznej i Antropologicznej. Świadczy to niewątpliwie o tym, że nie tylko znał osobiście J. Łepkowskiego, ale również posiadał wiedzę z zakresu archeologii, co potwierdza dodatkowo członkostwo Towarzystwa Archeologicznego w Moskwie. Sądzi się również, że na zlecenie J. Łepkowskiego doktor M. Żmigrodzki wykonał serię akwarel i rysunków waz greckich znajdujących się w Gabinecie. Jego przyjmuje się za prekursora badań nad ceramiką grecką w Polsce (Papuci-Władyka 2007: 228-230)

\section{INNE}

Na początku lat 70. XIX stulecia Tadeusz Korzon (1839-1918), wybitny twórca i przedstawiciel warszawskiej szkoły historycznej, podjął temat wydłużenia się dziejów ludzkości. W swoim artykule napisał:

W ciągu lat kilkunastu urosła nowa gałęź wiedzy, zwana archeologia przedhistoryczną. Bada ona życie pierwotnych budzi, o których żaden prawie ze starożytnych pisarzy nie uczynił wzmianki, którzy nie pozostawili po sobie ani piramid, ani pałaców, a wyszedłszy świeżo z łona natury, poczynili pierwsze, najprostsze, ale najważniejsze zdobycze i założyli pierwotne podwaliny historycznych cywilizacyj. Do postępu tych badań głównie przyłożyli rękę naturaliści i geologowie. Rezultaty są znakomite; uczeni odważają się już oznaczyć czas istnienia rodu ludzkiego na 50,000 lat i kreślić obrazy życia, wiar, obyczajów 
w tej zamierzchłej przeszłości, której ani historyka, ani filolog rozproszyć by nie mógł (Korzon 1871: 170).

Informacje na ten temat czerpał z literatury obcojęzycznej. Swoje rozważania prowadził od najdawniejszych dziejów. Opisał kolejno wiek kamienia ciosanego, kamienia szlifowanego, wiek brązowy i żelazny. W każdym z nich zwracając uwagę na rozwój człowieka i jego wyroby oraz surowiec, który wykorzystywał (Korzon 1871: 170-171, 186-187, 199).

Ciekawy jest fakt, że T. Korzon pisząc swój artykuł nie był zorientowany w aktualnej sytuacji archeologii na ziemiach polskich, w kontekście odkryć mieszkań nawodnych, o czym już wcześniej wspominałam (Korzon 1871: 199).

Dzieje człowieka przedpotopowego były również tematem często podejmowanym. Problematyka ta poruszona była w wykładzie, wygłoszonym w Warszawie, Juliana Ochorowicza (1850-1917), wynalazcy, filozofa, psychologa, publicysty - redaktora „Niwy”, propagującego idee pozytywizmu (Kronika... 1872a: 31; Krajewski 1987: 499).

W „Tygodniku” odnaleźć można również wiele wzmianek dotyczących działalności Towarzystwa Naukowego Krakowskiego i jego prac na rzecz archeologii. W 1862 r. Emil Kierski (1810-1874) publicysta, redaktor, badacz starożytności, od 1859 r. współpracownik Towarzystwa Przyjaciół Nauk w Poznaniu, początkowo pełnił tam funkcję bibliotekarza, a w późniejszym czasie stał się jednym z najaktywniejszych członków Wydziału Historyczno-Literackiego (Głowacka 1966-1967: 427-428). Informował o działalności i sytuacji Towarzystwa, które samodzielnie finansowało swoje prace. Najczynniejszym członkiem Oddziału Archeologicznego był J. Łepkowski. Autor tak podsumował jego działalność:

Z radością powitałem w Roczniku Towarzystwa naukowego jego rozprawę obejmującą wycieczki po wsiach i miasteczkach w Krakowskiem i Galicyi. Kraju naszego takim jak jest obecnie, prawie nie znamy, bo (mówię o Galicyi) nikt go nie opisuje; jeden Łepkowski wszędzie zajrzy, wszystko zapisuje skrzętnie (E[mil] K[ierski] 1862: 191).

W XIX wieku planowano uczczenie tysiąclecia objęcia panowania przez Ziemowita i dziewięćsetlecia chrztu. Organizatorzy uroczystych obchodów chcieli z tej okazji zorganizować wystawę starożytności polskich i słowiańskich oraz zjazd w Kruszwicy, w czasie którego miano usypać kopiec na cześć Piasta (wzorem kopców Krakusa i Wandy). Niezależnie od komitetu organizującego uroczyste obchody, dr Kazimierz Szulc (1824-1887) planował wydanie albumu z rysunkami, poezjami, wspomnieniami itp. Dochód z niego miał być przeznaczony na budowę pomnika Piasta. Planów tych nie zrealizowano. Ograniczono 
się do uroczystej Mszy Św. odprawionej 30 czerwca jubileuszowego roku 1863 (Korespondencja... 1864: 107-108).

W 1872 r. postanowiono wprowadzić w Galicji urząd Konserwatorów Rządowych, których zadaniem było czuwanie nad zabytkami starożytniczymi. W Galicji Zachodniej tę funkcję powierzono Pawłowi Popielowi (18071892), politykowi i publicyście, a w Galicji Wschodniej, Mieczysławowi hr. Potockiemu. Choć już w wcześniej zabiegano o uświadomienie społeczeństwa w zakresie ochrony zabytków i szacunku dla nich to pierwsza wskazówka, dotycząca właściwego postępowania ze starożytnościami, została opracowana w 1850 r., lecz wydano ją dopiero osiem lat później. W 1865 r. Oddział Archeologii i Sztuk Pięknych Towarzystwa Naukowego przygotowywał „Skazówkę", by upowszechnić główne zasady obowiązujące przy restauracji zabytków. Dotyczyła ona głównie kościołów wiejskich i była wzorowana na francuskiej instrukcji (Korespondencja... 1865: 151; Wiadomości... 1868b: 114).

W 1878 r. Komisja Archeologiczna wchodząca w skład Wydziału Historycznego Akademii Umiejętności stworzyła swój organ. Pierwszy zeszyt serii „Wykazu zabytków przedhistorycznych na ziemiach polskich”, był autorstwa Jana Nepomucena Sadowskiego (1814-1897). Nosił tytuł Porzecza Warty i Baryczy (Chmielowski 1878: 20).

Pozytywnie również ustosunkowano się do publikacji książkowych. W 1868 r. ukazała się, już po śmierci Konstantego Tyszkiewicza (1806-1868), jego rozprawa $O$ kurhanach na Litwie i Rusi Zachodniej. W warszawskim periodyku przyjęto ją dobrze, lecz zwrócono uwagę na fakt, że zostały wydane już inne pozycje, które zawierały najnowsze doniesienia w zakresie archeologii (Wiadomości... 1868a: 98-99).

Entuzjastycznie redakcja „Tygodnika Ilustrowanego” podchodziła do nowych inicjatyw wydawniczych z dziedziny archeologii. W $1880 \mathrm{r}$. na podstawie prospektu „Przeglądu bibliograficzno-archeologicznego”, w „Tygodniku Ilustrowanym" informowano, że nowe czasopismo zacznie się ukazywać od stycznia $1881 \mathrm{r}$. Na jego łamach poruszane miały być zagadnienia dotyczące nie tylko bibliografii i archeologii, ale także numizmatyki, heraldyki, sztuk pięknych i literatury. Dodatkowo zapowiedziano: rozprawy historyczne, życiorysy oraz korespondencję krajową i zagraniczną, przedruki ważniejszych dokumentów i nut, ,podobizny autografów”. Wszystko to miało zostać objaśnione i uzupełnione ilustracjami (Kronika... 1880b: 378). Pierwszy numer pisma oceniono pozytywnie, choć w stosunku do autora jednego z artykułów pojawił się zarzut o nadmierną erudycję i nieprzystępność (Kronika... 1881: 58). 
W warszawskim periodyku znalazła się także informacja o założeniu nowego pisma archeologicznego w Poznaniu. „Zapiski archeologiczne”, bo o nich mowa, ukazywały się również w wersji niemieckojęzycznej. Wydane zostały z inicjatywy Władysława Jażdżewskiego (1835-1895) i Bolesława Erzepkiego (1852-1932). Spotkały się one jednak z krytyką dzienników niemieckich, które przekonywały swoich czytelników, że żaden Niemiec „Zapisków” prenumerować nie powinien, gdyż miały zabarwienie tendencyjne. Jak sugeruje autor artykułu, wynikało to z obawy o losy „Zeitschrift der historischen Gesellschaft für die Provinz Posen", organu Niemieckiego Towarzystwa Historycznego (M. K. 1887: 43).

W 1885 r. pojawiła się w warszawskim periodyku notatka, w której autor podjął temat handlu zabytkami i nieznajomości wartości posiadanych artefaktów. Prowadziło to, jak podkreślono w Kronice Tygodniowej, do zaniedbania, a w konsekwencji zniszczenia wielu cennych zabytków. Dlatego wysunięto postulat, aby akcją informacyjną zajęli się specjaliści. Donoszono również, że wiele artefaktów po sprzedaży trafiało za granicę. Wynikało to z faktu, że w Warszawie pojawili się poszukiwacze zabytków, pośredniczący jednocześnie w handlu nimi. Nie mieli oni skrupułów, by zapewniać sprzedających, że przedmioty trafią w ręce polskich nabywców i pozostaną w kraju, gdy faktycznie wywożone były za granicę przez cudzoziemców. Tym właśnie sposobem, jak podkreślał autor, wiele ważnych dla historii polskiej eksponatów zaginęło (Kronika... 1885: 279).

\section{ZAKOŃCZENIE}

W pierwotnych założeniach twórców „Tygodnika Ilustrowanego” w piśmie miały dominować zagadnienia krajowe oscylujące w obrębie: literatury, kultury, sztuki i historii. W hierarchii podejmowanych tematów „Archeologia, opisy i widoki kościołów, zamków, pomników historycznych i innych zabytków przeszłości" (Unger 1859) twórcy warszawskiego periodyku umieścili na szóstej pozycji spośród trzynastu wymienionych.

Niewątpliwie szeroko rozumiany dział historyczny, w skład którego weszła archeologia, na łamach „Tygodnika” był wyraźnie widoczny i nigdy z niego nie zrezygnowano. Pierwszy redaktor pisma - Ludwik Jenike, przez 27 lat kierowania warszawskim periodykiem nigdy nie zdecydował się na ograniczenie publikacji dotyczących starożytności. Zjednywało mu to sympatię czytelników, ale jednocześnie powodowało ataki ze strony „młodej prasy”, która posądzała redakcję o konserwatyzm społeczny będący symbolem wstecznictwa prasy „starych” (Michałowska 1951: 16-18). 
Początkowo dominowały informacje dotyczące starożytności krajowych. O najdawniejszych dziejach pisali dla "Tygodnika Ilustrowanego": J. Łepkowski, F. M. Sobieszczański, W. Szymanowski, K. W. Wójcicki, J. I. Kraszewski. Po ich odejściu pojawiały się jedynie pojedyncze artykuły poruszające te zagadnienia, pisane przez autorów niezwiązanych z redakcją.

Od lat 70. XIX stulecia wzrosła liczba publikacji odnoszących się do starożytności zagranicznych. Wtedy, zgodnie z trendami panującymi w Europie, zaczęła dominować na ziemiach polskich archeologia o nastawieniu przyrodniczym. Warto również podkreślić, że podejmowana problematyka była odzwierciedleniem tendencji panujących w rozwoju tej dyscypliny nie tylko na ziemiach polskich, ale i okresowo w całej Europie.

Zmiana podejścia do archeologii w „Tygodniku” nastapiła w 1886 r. wraz $\mathrm{z}$ rezygnacją $\mathrm{z}$ pracy $\mathrm{w}$ redakcji L. Jenikego. Nowy właściciele - Firma Gebethner i Wolf oraz redaktor - Józef Wolf (1862-1918), postanowili odejść od dotychczasowego charakteru pisma, które nie przyciagało już nowych czytelników. Nie nastąpiło to jednak gwałtownie. Powoli i systematycznie ograniczano liczbę artykułów o treściach archeologicznych.

Jak słusznie zauważył Andrzej Abramowicz, wpływ na zmniejszenie ilości publikacji dotyczących starożytności miał również kryzys, który nastąpił w dziejach tej dyscypliny. Od połowy lat 80 . XIX stulecia malało grono badaczy zajmujących się tymi zagadnieniami. Luka jaka nastapiła po ich śmierci nie została od razu wypełniona przez kolejne pokolenie (Abramowicz 1967: 158).

Zamieszczane informacje nie ograniczały się jedynie do wiadomości o wykopaliskach. Na łamach „Tygodnika” umieszczano biogramy badaczy i kolekcjonerów wraz z opisem posiadanych przez nich zbiorów. Informowano o wystawach starożytności i muzeach gromadzących artefakty z czasów przedhistorycznych.

Zagadnienia archeologiczne, choć często poruszane na łamach „Tygodnika Ilustrowanego", to jednak nigdy nie znalazły one stałego miejsca w piśmie. Przez pewien czas J. Łepkowski, redagował rubrykę „Detale archeologiczno-architektoniczne”, w której jednak rzadko zamieszczał wiadomości o odkryciach i wykopaliskach. Swoją uwagę skupił raczej na sztuce i architekturze.

Fakt, że w omawianym okresie w „Tygodniku Ilustrowanym” dominowały doniesienia dotyczące starożytności krajowych może świadczyć o tym, jak poważnie odnoszono się do przeszłości w czasie, gdy ziemie polskie znajdowały się pod zaborami. Wtedy szczególnie zabiegano o to aby przetrwała pamięć o rodzimej historii, również tej najdawniejszej. Szczególnie dziennikarze i redaktorzy pism czuli się w obowiązku stać na jej straży (Abramowicz 1991: 43). 
Kończąc należy jeszcze podkreślić, że wnioski jakie uzyskano na podstawie analizy artykułów o treściach archeologicznych zamieszczonych w warszawskim periodyku niepodważalnie świadcza, jak ważnym źródłem do poznania historii tej nauki okazał się ,Tygodnik Ilustrowany”.

mgr Aleksandra Jeleń

Uniwersytet Łódzki

Wydział Filozoficzno-Historyczny

Instytut Archeologii

ul. Uniwersytecka 3

90-137 Łódź

\section{Bibliografia}

Abramowicz A. (1967), Wiek archeologii. Problemy polskiej archeologii dziewiętnastowiecznej, Warszawa.

Abramowicz A. (1991), Historia archeologii polskiej XIX i XX wiek, Warszawa-Lódź.

Abramowicz A. (1997), Rzeczy, idee i maski. Jacques Boucher de Perthes (1788-1868), Warszawa.

Archeologia... (1909), Archeologia. Życie polskie w dawnych wiekach. Pamiatki polskie na obczyźnie, „Tygodnik Ilustrowany”, nr 50, s. 1045-1046.

Blombergowa M. M. (2003), Pierwsi archeolodzy w Jurze Ojcowskiej, „Analecta. Studia i Materiały z Dziejów Nauki”, R. XII, z. 1-2, s. 131-144.

Chmielowski P. (1878), Działalność Akademii Umiejętności w Krakowie, „Tygodnik Ilustrowany", t. VI, nr 133, s. 19-20.

Czernicki G. (1865), Korespondencja Tygodnika Ilustrowanego. Kraków, „Tygodnik Ilustrowany", t. XII, nr 322, s. 222.

Domaradzki (1871), Wykopaliska nadziejewskie, „Rocznik Towarzystwa Przyjaciół Nauk Poznańskiego", t. VI, s. 202-218.

Doniesienia (1860), Doniesienia, ,Tygodnik Ilustrowany”, t. I, nr 15, s. 123.

E. (1867), Ksawery Godebski, ,Tygodnik Ilustrowany”, t. XV, nr 381, s. 13.

E[mil] K[ierski] (1862), Korespondencja Tygodnika Ilustrowanego. Z Galicyi, „,Tygodnik Ilustrowany", t. VI, nr 163, s. 191.

Fischer A. (1927), Zakład Naukowy Imienia Ossolińskich. Zarys dziejów, Lwów, http://www.lwow.home.pl/ossolineum/ossolineum2.html (dostep: 25.05.2011 r). 
Fita S. (1980), Pokolenie Szkoty Gtównej, Warszawa.

Fogel J. (1991), Pompeja polska. Z dziejów archeologii wielkopolskiej XIX wieku: dziatalność Albina hr. Węsierskiego i Zbigniewa hr. Węsierskiego-Kwileckiego, Poznań.

Gloger Z. (1880), Ludwik Pawłowski, ,Tygodnik Ilustrowany”, t. IX, nr 210, s. 10-11.

Głowacka A. (1966-1967), Kierski Emil, [w:] Polski Słownik Biograficzny, t. XII, Kraków, s. 427-428.

Jenike L. (1910), Ze wspomnień, cz. I, Warszawa.

Korespondencja...(1864), Korespondencja Tygodnika Ilustrowanego, „Tygodnik Ilustrowany", t. IX, nr 234, s. 107-108.

Korespondencja... (1865), Korespondencja Tygodnik Ilustrowanego. Kraków. „Tygodnik Ilustrowany", t. XI, nr 291, s. 151.

Korespondencja... (1869), Korespondencja Tygodnika Ilustrowanego, „Tygodnik Ilustrowany", t. III, nr 65, s. 154.

Korespondencja... (1870), Korespondencja Tygodnika Ilustrowanego. Lwów, „Tygodnik Ilustrowany", t. VI, nr 145, s. 177-178.

Korzon T. (1871), Ludzie przedhistoryczni. Zarys pierwotnych dziejów rodzaju ludzkiego, „Tygodnik Ilustrowany”, t. VII, nr 171, s. 170-171, nr 172, s. $186-187$; nr 174, s. 198-199.

Kozerska H. (1967), Warszawska Biblioteka Uniwersytecka w latach 1832-1871, Warszawa.

Krajewski J. (1987), Ochorowicz Julian Leopold, [w:] Polski Słownik Biograficzny, t. XXX, Kraków, s. 499-505.

Kraszewski J. I. (1860), Sztuka u Słowian, szczególnie w Polsce i Litwie przedchrześcijańskiej, Wilno.

Kronika... (1872a), Kronika Tygodniowa, ,Tygodnik Ilustrowany”, t. IX, nr 212, s. 31.

Kronika... (1872b), Kronika Tygodniowa, ,Tygodnik Ilustrowany”, t. X, nr 256, s. 246.

Kronika... (1875), Kronika Tygodniowa, „Tygodnik Ilustrowany”, t. XVI, nr 394, s. 34.

Kronika... (1880a), Kronika Tygodniowa, „Tygodnik Ilustrowany”, t. X, nr 240, s. 74.

Kronika... (1880b), Kronika Tygodniowa, „Tygodnik Ilustrowany”, t. X, nr 259, s. 378.

Kronika... (1881), Kronika Tygodniowa, „Tygodnik Ilustrowany”, t. XI, nr 265, s. 58.

Kronika... (1884), Kronika Tygodniowa, „Tygodnik Ilustrowany”, t. III, nr 54, s. 23.

Kronika... (1885), Kronika Tygodniowa, „Tygodnik Ilustrowany”, t. VI, nr 148, s. 279.

Kryński A. A. (1882), Józef Przyborowski, „Tygodnik Powszechny”, t. XIII, nr 325, S. 162. 
Łepkowski J. (1866), O starożytnych mieszkalnych budowlach na palach, wznoszonych wśród jezior $i$ na rzekach, „Tygodnik Ilustrowany”, t. XIII, nr 330, s. 28-30.

Łepkowski J. (1871), Szczatki mieszkań nawodnych w Czeszewie, „Tygodnik Ilustrowany", t. VIII, nr 199, s. 200-201.

M. K. (1887), Korespondencja „, Tygodnika ilustrowanego”. Poznań, „Tygodnik Ilustrowany", t. X, nr 237, s. 42-43.

Michałowska B. (1951), Pierwsze dziesięciolecie „Tygodnika Ilustrowanego”, Wrocław.

Muszalski E. (1978), Niewiadomski Wincenty, [w:] Polski Słownik Biograficzny, t. XXIII, s. 78-79.

Muzeum... (1869), Muzeum starożytności w Warszawie, „Tygodnik Ilustrowany”, t. IX, nr 100, s. 264-265.

Niewiadomski W. (1870), Korespondencja Tygodnika Ilustrowanego. Wrocław, „Tygodnik Ilustrowany”, t. V, 1870, nr 118, s. 159.

Ostrowski J. A. (2002), Józef Aleksander Łepkowski (1826-1894) - twórca uniwersyteckiego Gabinetu Archeologicznego, „Alma Mater”, nr 41, http://www3.uj. edu.pl/alma/alma/41/01/08.html (dostęp: 20.05.2011 r.)

Papuci-Władyka E. (2007), Michał Żmigrodzki (1848-1919) jako jeden z prekursorów polskich badań nad ceramika grecka, [w:] Egipt, Grecja, Italia. Zabytki starożytne z dawnej kolekcji Gabinetu Archeologicznego Uniwersytetu Jagiellońskiego, red. J. Śliwa, Kraków, s. 219-230.

Plenkiewicz R. (1883), Teraźniejszość i przyszłość Ojcowa, „Tygodnik Ilustrowany”, t. I, nr 22, s. 350-351.

Plenkiewicz R. (1884), Grota Maszyca pod Ojcowem, „Tygodnik Ilustrowany”, t. III, nr 55, s. 45-46.

Przezdziecki A. (1869), Wykopaliska na wyspie na jeziorze Lednicy, pod Gnieznem, „Biblioteka Warszawska”, t. III, nr 114, 115, 116.

Ryszkiewicz A. (1987), Rastawiecki Edward, [w:] Polski Słownik Biograficzny, t. XXX, Kraków, s. 600-603.

Skręt R. (1986), Przyborowski Józef Tomasz, [w:] Polski Słownik Biograficzny, t. XXIX, Kraków, s. 76-79.

Skręt R. (1997-1998), Skombrowicz Hipolit, [w:] Polski Stownik Biograficzny, t. XXXVIII, Kraków, s. 159-161.

Silva... (1885) Silva Rerum, ,Tygodnik Ilustrowany”, t. VI, nr 140, s. 159.

Sobieszczański F. M. (1870), Starożytności wykopane pod Gnieznem, „Tygodnik Ilustrowany", t. V, nr 106, s. 16. 
Szczerba A. (2012), Problem ochrony zabytków archeologicznych na ziemiach dawnej Rzeczpospolitej pod panowaniem rosyjskim, Łódź.

Szymanowski W. (1871), Kronika Tygodniowa, „Tygodnik Ilustrowany”, t. VIII, nr 185, s. 26.

Unger J. (1859), Prospekt Tygodnika Illustrowanego, Warszawa.

Wiadomości... (1868a), Wiadomości bibliograficzne (Archeologia. Sztuki piękne), „Tygodnik Ilustrowany”, t. II, 35, s. 98-99.

Wiadomości... (1868b), Wiadomości bibliograficzne (Archeologia. Sztuki piękne), „Tygodnik Ilustrowany”, t. II, 36, s. 114.

Wiadomości... (1869a), Wiadomości bibliograficzne. (Archeologia i sztuki piękne), „Tygodnik Ilustrowany”, t. III, nr 71, s. 227-228.

Wiadomości... (1869b), Wiadomości bibliograficzne. (Archeologia i sztuki piękne), „Tygodnik Ilustrowany”, t. IV, nr 82, s. 43.

Wrońska-Twardecka J. (1997), Recepcja osiagnięć archeologii europejskiej $w$ badaniach nad epoka kamienia (od pozytywizmu do okresu międzywojennego), [w:] Archeologia i starożytnicy. Studia dedykowane Profesorowi Andrzejowi Abramowiczowi w 70 rocznice urodzin, red. M. Głosek, Łódź, s. 315-320.

Zawadzki W. (1864), Korespondencja Tygodnika Ilustrowanego, „Tygodnik Ilustrowany", t. X, nr 258, s. 330-331.

Żmigrodzki M. (1877), Pamiatki przeszłości. Pare godzin spędzonych w gabinecie archeologicznym uniwersytetu Jagiellońskiego, „Tygodnik Ilustrowany”, 1877, t. III, nr 63, s. 151; nr 64, s. 164-167; nr 65, s. 186. 


\title{
SUMMary
}

\section{NATIONAL ARCHEOLOGY \\ IN “TYGODNIK ILUSTROWANY” UNTIL 1886}

\begin{abstract}
"Tygodnik Ilustrowany", one of the most popular Warsaw periodicals, was coming out between 1859-1939. The aim of its founders was to create a magazine that would address national issues, including our past.

The historical section, in which archeological topics found a place, was visible part of the "Tygodnik Ilustrowany". The first editor of the magazine, Ludwik Jenike, for 27 years of managing the Warsaw periodical (that is the whole discussed period) never decided to limit publications connected with antiquity. However the archeological issues did not find a permanent place in the magazine. The following antiquarians were writing for the "Tygodnik Ilustrowany": Józef Łepkowski, Franciszek Maksymilian Sobieszczański, Wacław Szymanowski, Kazimierz Władysław Wójcicki, Józef Ignacy Kraszewski. It must be underlined that the published information on archeological topics was not limited just to the news about excavations or accidental discoveries. The scholars' and collectors' biographical entries with precise descriptions of their findings as well as information on ancient exhibitions and museums that gather the monuments from prehistoric times were also included in the "Tygodnik Ilustrowany". The history was treated with all seriousness during the $19^{\text {th }}$ century, because the memory of the past, including the most remote times, was the sign of patriotism.
\end{abstract}

